\title{
PENYELESAIAN KREDIT BERMASALAH PADA PT. BANK PERKREDITAN RAKYAT (BPR) MITRA DANAGUNG PADANG
}

\author{
Nurasiah, Mariani St.B Tanjung \\ Akademi Keuangan dan Perbankan Padang \\ mstbtanjung@gmail.com
}

\begin{abstract}
ABSTRAK
Penelitian ini bertujuan untuk mengetahui Apa yang menyebabkan terjadinya kredit bermasalah pada PT. BPR Mitra Danagung, Bagaimana cara penyelesaian kredit bermasalah pada PT. BPR Mitra Danagung. Metode analisis data yang diperlukan untuk menulis tugas akhir ini adalah metode deskriptif yaitu dengan menguraikan data secara sistematis dari fakta-fakta yang didapat kemudian dihubungkan dengan prosedur penyelesaian kredit bermasalah pada PT. Bank Perkreditan Rakyat (BPR) Mitra Danagung Padang. PT. Bank Perkreditan Rakyat (BPR) Mitra Danagung merupakan bank yang bergerak dibidang memberikan pinjaman dalam bentuk kredit yang tujuannya adalah untuk membantu masyarakat yang kekurangan dana yang berada disekitar kota padang. Dalam pelaksanaan pengawasan kredit PT BPR Mitra Danagung didasarkan penelitian ketempat lokasi usaha debitur serta atas laporan-laporan yang diberikan oleh nasabah. Untuk keamanan dari kredit yang diberikan kepada nasabah, maka PT BPR Mitra Danagung meminta adanya jaminan kredit kepada calon nasabah. Penyehatan kredit bermasalah yang dilakukan oleh PT BPR Mitra Danagung dapat dilakukan dengan cara kombinasi yaitu dengan cara memberi surat tunggakan dan surat peringatan kepada debitur, memberikan keringanan pembayaran bunga dan tunggakan pokok, serta mendesak debitur untuk menjual agunan. Penyebab utama dari kredit bermasalah bisa saja karena kesalahan dari pihak bank yang kurang tajam dalam menganalisis latar belakang calon nasabah, sehingga maksud dan tujuan serta sumber pembayaran kembali kredit yang diberikan tidak dapat diketahui secara jelas. Rendah nya tingkat pendidikan nasabah yang menerima kredit, serta kurang adanya komunikasi yang terbuka antara nasabah dengan bank juga dapat menyebabkan terjadinya kredit bermasalah.
\end{abstract}

Kata Kunci: Kredit Bermasalah

\section{PENDAHULUAN}

Perbankan merupakan sektor terpenting dalam laju perekonomian suatu negara. Semua permasalahan yang dihadapi oleh dunia perbankan, sangat 
mempengaruhi semua tatanan yang berhubungan dengan laju pertumbuhan ekonomi. Dalam industri perbankan pada saat ini, masalah yang banyak dihadapi adalah masalah dalam pengambilan kredit, sehingga harus mendapatkan perhatian serius.

Bagi masyarakat kredit sangat diperlukan dalam mendukung dan mengembangkan usahanya, dimana dengan menggunakan dana kredit bisa digunakan untuk pengadaan atau peningkatan berbagai faktor produksi baik berupa tambahan modal kerja, bahan baku, perluasan pasar, peningkatan kemampuan sumber daya manusia, sumber daya alam, teknologi dan lain sebagainya.

Setiap penyaluran kredit oleh kreditur tentu mengandung resiko, karena adanya keterbatasan kemampuan manusia dalam memprediksi masa yang akan datang, untuk itu bank harus merencanakan sedemikian rupa dan berusaha untuk menekan resiko munculnya kredit bermasalah. Pihak bank juga perlu menilai kelayakan usaha dari debitur dan juga diperlukan adanya pengelolaan dan pengawasan, sehingga kesinambungan usaha perbankan tetap terjaga.

Dalam menyalurkan kredit kepada masyarakat tidak keseluruhan dana yang disalurkan tersebut dapat dikembalikan seluruhnya atau sebagaimana mestinya, maka hal inilah yang menjadi penyebab timbulnya kredit bermasalah.

Kredit bermasalah dapat diartikan sebagai ketidak sanggupan debitur untuk melunasi pinjamannya kepada bank berupa angsuran pokok dari pinjaman beserta bunganya, serta biaya lain dimana mengalami kegagalan karena deviasi (penyimpangan) sehingga tidak sesuai dengan perjanjian yang telah disepakati yang akhirnya dapat membawa kerugian kepada PT. BPR Mitra Danagung.

Kredit bermasalah timbul tidak dengan seketika melainkan secara bertahap dimana terjadi penurunan berbagai aspek yang dimiliki debitur yang berakhir dengan ketidak mampuan debitur membayar kreditnya.

Mencari penyebab kredit bermasalah adalah sulit karena banyak faktor yang mempengaruhi baik yang bersifat intern maupun ekstern. Faktor ekstern "berasal dari luar perusahaan" seperti keadaan ekonomi, persaingan, bencana alam dan dari debitur itu sendiri. Sedangkan faktor intern "berasal dari dalam pihak perusahaan" seperti kesalahan penilaian dalam pemberian kredit atau minimnya pengawasan dan pembinaan terhadap kredit yang disalurkan.

Kredit bermasalah merupakan disebabkan berbagai faktor yang berkaitan satu sama lainnya, untuk itu harus segera mungkin mendapatkan penyelesaian karena dapat menyebabkan terganggunya kondisi bank.

Berdasarkan uraian diatas maka penulis tertarik untuk menuangkannya dalam bentuk tugas akhir dengan judul Penyelesaian Kredit Bermasalah Pada PT. Bank Perkreditan Rakyat (BPR) Mitra Danagung Padang.

PT. BPR Mitra Danagung sebagai badan usaha yang bergerak menghimpun dana masyarakat dan menyalurkan dana tersebut dalam bentuk kredit. Tentunya peranan pengelola dalam mengurangi resiko yang akan terjadi sangat besar. Untuk lebih terarahnya tugas akhir ini, maka penulis lebih mengkhususkan kepada: 
a. Apa yang menyebabkan terjadinya kredit bermasalah pada PT. BPR Mitra Danagung?

b. Bagaimana cara penyelesaian kredit bermasalah pada PT. BPR Mitra Danagung?

\section{METODE PENELITIAN}

Dalam mempersiapkan laporan tugas akhir ini, penulis melakukan penelitian guna memperoleh data-data dan informasi yang diperlukan.

Penelitian tersebut dilakukan dengan cara :

\section{Metode Pengumpulan Data}

a. Penelitian Keperpustakaan (Library Research)

Penelitian Keperpustakaan Library Research yaitu penelitian keperpustakaan, mencari landasan teori dengan mempelajari buku-buku bacaan, literatur-literatur, bahan-bahan kuliah serta artikel-artikel yang berhubungan dengan topik pembahasan.

b. Penelitian Lapangan (Field Research)

Penelitian Lapangan Field Research yaitu dengan melakukan penelitian langsung ke PT. BPR Mitra Danagung Padang dengan melakukan wawancara dan tanya jawab guna mendapatkan data-data dan keteranganketerangan yang erat kaitannya dengan penulisan ini.

\section{Metode Analisis Data}

Metode analisis data yang diperlukan untuk menulis tugas akhir ini adalah metode deskriptif yaitu dengan menguraikan data secara sistematis dari fakta-fakta yang didapat kemudian dihubungkan dengan prosedur penyelesaian kredit bermasalah pada PT Bank Perkreditan Rakyat (BPR) Mitra Danagung Padang.

\section{LANDASAN TEORI}

\section{Pengertian Kredit Bermasalah}

Kredit bermasalah menurut Rivai (2006:476) yaitu :

1. Kredit yang dalam pelaksanaannya belum mencapai/memenuhi target yang diinginkan oleh pihak bank.

2. Kredit yang memiliki kemungkinan timbulnya resiko dikemudian hari bagi bank dalam arti luas.

3. Kredit golongan perhatian khusus, kurang lancar, diragukan, dan macet serta golongan lancar yang berpotensi menunggak.

Menurut Sutojo (2008:13) kredit dapat dikatakan bermasalah apabila:

1. Terjadi keterlambatan pembayaran bunga dan/atau kredit induk lebih dari 90 hari sejak tanggal jatuh temponya.

2. Tidak dilunasi sama sekali.

3. Diperlukan negosiasi kembali atas syarat pembayaran kembali kredit dan bunga yang tercantum dalam perjanjian kredit.

Pengertian kredit bermasalah berdasarkan penetapan kualitas kredit mencakup kualitas kredit sebagai berikut : 
1. Lancar, namun diperkirakan akan mengalami kesulitan pembayaran pokok dan/atau bunga kredit.

2. Dalam Perhatian Khusus,

3. Kurang Lancar

4. Diragukan,

5. Macet.

Pengertian kredit bermasalah berdasarkan pencatatan kredit dalam pembukuan Bank adalah sebagai berikut :

1. Kredit yang tercatat dalam aktiva Bank.

2. Kredit yang telah di hapus buku (write off) atau yang secara administrasi Bank dicatat dalam Rekening Administratif atau Ekstrakomtabel.

3. Kredit yang telah dihapus tagih.

\section{Prinsip Penanganan Kredit Bermasalah}

Prinsip-prinsip yang harus dijadikan acuan dan pedoman oleh Satuan

Kerja Perkreditan Khusus (SKPK) baik dikantor Cabang maupun dikantor Pusat dalam penanganan kredit bermasalah adalah :

1. Bank tidak membiarkan bahkan menutup-nutupi adanya kredit bermasalah.

2. Bank melakukan identifikasi dan mendeteksi secara dini adanya kredit bermasalah atau kredit yang diperkirakan dan berpotensi akan menjadi kredit bermasalah.

3. Penanganan kredit bermasalah atau kredit yang diperkirakan dan berpotensi akan menjadi kredit bermasalah dilakukan secara dini dan segera mungkin untuk meminimalisasi risiko kredit bermasalah.

4. Bank tidak akan melakukan penyelesaian kredit bermasalah dengan cara menambah plafond kredit untuk melunasi tunggakan bunga kredit yang lazim disebut dengan plafondering kredit.

5. Bank tidak melakukan pengecualian dalam penyelesaian kredit bermasalah kepada Pihak Terkait, Kelompok Debitur dan Debitur inti.

\section{Penyebab Kredit Bermasalah}

Secara umum, penyebab munculnya kredit bermasalah dapat dikelompokkan kepada 3 (tiga) penyebab itu : faktor intern Bank, faktor debitur dan faktor ekstern.

1. Faktor Intern :

a. Bank melakukan Kebijakan pemberian kredit yang terlalu ekspansif dan agresif untuk mengejar target pemberian dan pertumbuhan kredit yang tinggi dalam waktu relatif singkat sehingga prosedur pemberian kredit yang sehat terabaikan.

b. Bank tidak melakukan penyebaran risiko dalam kebijakan pemberian kredit.

c. Kelemahan pada tahap Analisis Pemberian Kredit, antara lain :

1) Tidak akurat dalam menganalisis karakter debitur, kelayakan usaha, struktur keuangan, analisis risiko dan persyaratan pengamanan kredit. 
2) Kredit yang diberikan kepada usaha yang tergolong kriteria kredit berisiko tinggi.

3) Kredit yang diberikan kepada perusahaan baru yang dikelola pengusaha yang belum berpengalaman.

4) Tidak melakukan verifikasi terhadap dokumen pendukung yang diserahkan debitur kepada Bank.

5) Tidak memperhatikan dan mengabaikan informasi dari pihak ketiga atas karakter calon peminjam/nasabah.

6) Tidak meminta informasi bank untuk mengetahui performance debitur.

7) Tidak meninjau dan meneliti fasilitas produksi milik debitur.

8) Taksasi agunan kredit terlalu tinggi (over estimate) dari nilai sebenarnya.

9) Penambahan kredit tanpa agunan yang cukup.

10) Tidak melakukan analisis terhadap arus kas dan kemampuan membayar (repayment capasity) calon peminjam/nasabah.

11) Analisi kredit dilakukan oleh Pejabat Kredit yang mempunyai hubungan pribadi dan atau yang menimbulkan konflik kepentingan.

12) Terdapat campur tangan yang mengakibatkan analisis kredit tidak independen.

d. Kelemahan pada tahap Perjanjian Kredit, antara lain :

1) Perjanjian kredit berikut perjanjian turutannya tidak sempurna sehingga menempatkan bank pada posisi yang lemah.

2) Pengikatan Agunan Kredit tidak sempurna.

e. Kelemahan dalam tahap pencairan kredit, angtara lain :

1) Penarikan dana kredit dilakukan sebelum dokumen kredit dipenuhi atau diselesaikan.

2) Penarikan dana kredit tidak sesuai dengan tujuan penggunaan.

3) Penarikan dana kredit tidak memperhitungkan kewajiban penyediaan dana sendiri (self financing) debitur.

4) Penarikan dana kredit tidak dilengkapi dengan dokumendokumen yang dipersyaratkan.

f. Kelemahan dalam sistem pengawasan kredit, antara lain :

1) Tidak melakukan monitoring terhadap kredit yang telah diberikan sehingga komunikasi dengan debitur tidak intensif dan perkembangan usaha debitur tidak diketahui.

2) Terlambat atau tidak melakukan tindak lanjut atas indikasi problem kredit yang ditemukan.

g. Terjadinya kelemahan dalam sistem dokumentasi dan administrasi kredit.

2. Faktor Debitur :

a. Itikad yang tidak baik dari debitur dan sengaja melakukan perbuatan melawan hukum terhadap bank dengan bermacam modus operandi, antara lain dideteksi dari sikap dan perbuatan debitur sebagai berikut : 
1) Kurang mempunyai motivasi.

2) Angkuh dan merasa paling tahu.

3) Egois.

4) Suka berjudi.

5) Punya pola hidup mewah.

6) Menghindar dan atau melarikan diri.

7) Menggunakan agunan fiktif.

8) Memalsukan tanda tangan.

9) Menjual barang agunan dibawah tanagan.

10) Terlibat skandal.

b. Kelemahan Manajemen, antara lain :

1) Struktur permodalan atau keuangan sangat lemah.

2) Prospek keuangan kurang baik.

3) Kurang pengalaman dalam mengelola usaha sesuai dinamika kondisi dan situasi yang berkembang.

4) Terjadi perselisihan antar pengurus maupun dengan tenaga kerja.

5) Terjadinya tindakan penyelewengan keuangan dalam perusahaan.

c. Kelemahan produk dari usaha yang dibiayai Bank, antara lain :

1) Sumber bahan baku dan teknologi sulit diperoleh.

2) Kapasitas produksi tidak optimal dan atau rendah.

3) Mengalami kegagalan produksi.

4) Harga produk merosot.

5) Siklus usaha menurun.

6) Pasar sudah jenuh.

7) Produk yang dihasilkan kalah bersaing.

8) Produk tidak sesuai dengan selera pasar.

9) Lemah dalam promosi.

10) Tidak mempunyai layanan purna jual.

11) Investasi tidak seimbang.

12) Biaya operasional tinggi.

13) Aktiva Tetap berlebihan .

d. Kelemahan dalam penggunaan dana kredit, antara lain :

1) Kredit modal kerja digunakan untuk investasi dan sebaliknya.

2) Kredit untuk usaha digunakan untuk tujuan konsumsi.

3) Kredit digunakan untuk pembayaran tunggakan kredit.

4) Kredit digunakan untuk melunasi kredit lain.

5) Kredit digunakan untuk usaha lain diluar usaha pokok yang dikuasai debitur.

6) Kredit atas nama orang lain (kredit topengan).

e. Terjadinya musibah yang dialami langsung oleh debitur, seperti :

1) Meninggal dunia dan ahli waris tidak ada atau tidak mempunyai kemampuan untuk menjalankan usaha debitur.

2) Sakit keras yang sulit disembuhkan.

3) Kecelakaan fatal. 
4) Mengalami penipuan.

5) Rumah tangga pecah.

3. Faktor Ekstern :

a. Kondisi perekonomian/politik/kebijakan pemerintah yang diluar jangkauan untuk diperkirakan.

b. Adanya tekanan-tekanan dari berbagai kekuatan politis di luar Bank.

c. Terjadinya bencana alam.

d. Kesulitan dalam proses likuidasi atau eksekusi agunan karena faktorfaktor diluar Bank.

\section{Tujuan Penyelesaian Kredit Bermasalah}

Penanganan dan penyelesaian kredit bermasalah bertujuan untuk :

1. Menjaga dan memperbaiki rasio uncollectibility dan Non Performing Loan (NPL) yang digolongkan sehat sesuai dengan bussiness Plan Bank dan/atau Peraturan Bank Indonesia.

2. Meningkatan kesehatan Bank.

3. Memperoleh kembali dana Bank dan sekaligus meningkatkan pendapatan.

4. Menjaga kesinambungan usaha Bank.

\section{Identifikasi Dan Strategi Penyelesaian Kredit Bermasalah}

1. Identifikasi Penyelesaian

Untuk mencapai sasaran dan tujuan dalam penyelesaian kredit bermasalah, Bank melakukan identifikasi dan analisa permasalahan untuk penyelesaian kredit bermasalah yang merupakan dasar dalam penetapan strategi guna memperkecil kerugian, dengan fokus penilaian terhadap: kemampuan membayar, kecukupan agunan dan kredibilitas manajemen debitur dengan proses analisa sebagai berikut:

a. Melakukan identifikasi terhadap permasalahan yang dihadapi oleh debitur dengan memfokuskan kepada penelitian gejala dan penyebab terjadinya kredit bermasalah serta menentukan permasalahan yang tengah dihadapi oleh debitur.

b. Melakukan analisis secara menyeluruh, cepat dan tepat dari permasalahan untuk menentukan sejauh mana kerugian yang terjadi.

2. Strategi Penyelesaian

Strategi yang tepat sangat menentukan keberhasilan yang maksimal dalam penyelesaian kredit bermasalah, sehingga kerugian terhadap kredit bermasalah akan dapat ditekan seminimal mungkin. Untuk menetapkan strategi penyelesaian kredit bermasalah dilakukan langkah-langkah sebagai berikut :

a. Menginventarisir permasalahan yang dihadapi oleh debitur, terhadap fokus penilaian meliputi Kemampuan membayar, Agunan dan Kredibilitas Manajemen Debitur.

b. Menentukan sasaran strategi yang optimal dengan memperbaiki fokus yang dinilai dan memperkuat agar risiko kredit tidak terlalu besar atau 
tinggi, karena kelemahan dari salah satu fokus yang dinilai dapat melemahkan fokus lainnya.

c. Mempertimbangkan berbagai macam strategi untuk memperbaiki fokus yang lemah dan didukung suatu rencana tindakan (Action Plan) yang terinci dan jelas, misalnya dengan cara sebagai berikut :

1) Kelemahan kemampuan membayar debitur, dapat diperbaiki dengan melakukan cara :

a) Efisiensi atau penghematan biaya operasional usaha

b) Menjual aktiva yang tidak produktif

c) Menjadwalkan kembali angsuran kredit sesuaikemampuan cash flow.

d) Dan lain-lain.

2) Kelemahan dari agunan kredit, dapat dilakukan dengan meminta tambaha agunan kepada debitur.

3) Kelemahan dari kredibilitas manajemen debitur, dapat dilakukan dengan pembinaan dan penggantian manajemen.

d. Melakukan pemilihan strategi yang terdiri dari 2 (dua) pilihan yaitu : "Memutuskan Hubungan Kredit" dan atau "Meneruskan Hubungan Kredit". Pemilihan dari salah satu strategi tersebut harus didukung oleh rencana tindakan (Action Plan) yang kongkrit.

e. Membuat rencana tindakan (Action Plan) yang kongkrit untuk pedoman pelaksanaan strategi antara lain :

1) Menentukan tugas-tugas yang akan dilaksanakan secara jelas dan rinci.

2) Menentukan batas atau target waktu pelaksanaan dari tugastugas atau langkah tindakan.

3) Menetapkan atau mendelegasikan tanggung jawab dan kewenangan untuk pelaksanaan tugas-tugas atau langkah tindakan.

4) Menentukan hasil yang diharapkan.

\section{Tahapan Penyelesaian Kredit Bermasalah}

Dalam rangka penyelesaian Kredit Bermasalah, PT BPR Mitra Danagung Padang melakukan tahapan-tahapan dalam penyelesaian, sehingga tujuan dan sasaran yang hendak dicapai terlaksana sebagaimana yang diharapkan.

1. Tahapan Pemantauan

Bank melakukan pemantauan secara intensif dan disiplin terhadap portofolio kredit secara keseluruhan untuk mengantisipasi resiko kerugian dengan melakukan hal-hal sebagai berikut :

a. Meneliti Kualitas Kredit.

b. Melibatkan Audit Intern dalam pengawasan pemberian kredit.

c. Menetapkan dan menentukan debitur-debitur yang kualitas kreditnya berubah dan Lancar menjadi Dalam Perhatian Khusus, Kurang Lancar, Diragukan dan atau Macet. 
2. Tahapan Pengawasan

Bank melakukan analisa permasalahn dan evaluasi secara berkala untuk memperbaiki kualitas kredit dengan melakukan hal-hal sebagai berikut :

a. Menetapkan dan mementukan unit kerja pengelola kredit sebagai berikut :

1) Klasifikasi kredit dengan kualitas Lancar dan dalam Perhatian Khusus dikelola oleh Satuan Kerja Perkreditan Cabang (SKPC).

2) Klasifikasi kredit bermasalah yaitu : kredit dengan kualitas Kurang Lancar, Diragukan dan Macet serta kredit ekstrakomtabel dikelola oleh Satuan Kerja Perkreditan Khusus (SKPK) Cabang dibantu oleh Satuan Kerja Perkreditan Khusus (SKPK) Kantor Pusat.

b. Membuat analisa permasalahan dan rekomendasi penyelesaian setiap terjadi perubahan kualitas kredit Debitur, Kelompok Debitur dan Debitur Inti dari kualitas Lancar menjadi Dalam Perhatian Khusus, Kurang Lancar, Diragukan dan atau Macet dan untuk selanjutnya dibuat secara berkala dengan aturan sebagai berikut :

1) Analisa permasalahan dan rencana tindakan penyelesaian kredit bermasalah terhadap debitur-debitur dengan kualitas kredit Dalam Perhatian Khusus dilakukan setiap 1(satu) bulan sekali.

2) Analisa permasalahan dan rencana tindakan penyelesaian kredit bermasalah terhadap debitur-debitur dengan kualitas krtedit Kurang Lancar dan Diragukan serta Macet dibuat secara triwulan

3) Kerangka analisa permasalahan penyelesaian kredit bermasalah dapat dipedomani hal-hal sebagai berikut :

a) Analisa masalah minimal menginformasikan hal-hal sebagai berikut :

(1) Riwayat hubungan Debitur, kelompok Debitur dan Debitur Inti dengan Bank.

(2) Alasan dan penyebab terjadinya tunggakan kredit.

(3) Analisa penyelesaian kredit bermasalah.

b) Penetapan Strategi minimal menginformasikan hal-hal sebagai berikut :

(1) Perkiraan hasil yang diharapkan.

(2) Sasaran penyelesaian kredit bermasalah.

(3) Strategi penyelesaian.

(4) Strategi Alternatif (second way out)

(5) Rencana Tindakan (action plan) 


\section{Tindakan Penyelamatan Kredit Bermasalah Pada BPR Mitra Danagung Padang}

Jika bank telah memutuskan untuk melakukan tindakan penyelamatan kredit bermasalah tentu saja tergantung dari kesulitan yang dihadapi oleh nasabah, maka pilihan tindakan yang dapat diambil dapat melalui lima cara :

1. Reschedulling

Adalah suatu usaha penyelamatan kredit dengan cara memperpanjang waktu pelunasan atau perubahan besarnya angsuran pada setiap periode. Tindakan ini dapat diberikan jika :

1. Masalah yang dihadapi hanya kesulitan likuiditas sementara .

2. Debitur bersikap kooperatif atau jujur.

3. Manajemen dan sasaran produksi berjalan baik

4. Prospek usaha dapat diharapkan

5. Penyelamatan lebih baik daripada likuidasi

2. Rekonditioning

Adalah suatu usaha untuk memungkinkan pengambilan hutang oleh debitur dengan cara memberikan berupa perubahan syarat-syarat, seperti penyesuaian suku bunga.

Dalam hal ini bantuan yang diberikan adalah berupa keringanan atau perubahan persyaratan kredit, antara lain :

a) Kapitalisasi bunga, yaitu bunga dijadikan utang pokok sehingga nasabah untuk waktu tertentu tidak perlu membayar bunga, tetapi hutang pokoknya dapat melebihi plafon yang disetujui. Cara ini ditempuh dalam hal prospek usaha nasabah baik.

b) Penundaan pembayaran bunga, yaitu bunga tetap dihitung, tetapi penagihan atau pembebanannya kepada nasabah tidak dilaksanakan sampai nasabah mempunyai kesanggupan. Atas bunga yang terhutang tersebut tidak dikenakan bunga dan tidak menambah plafon kredit.

c) Pembebasan bunga, yaitu dalam hal nasabah memang dinilai tidak sanggup membayar bunga karena usaha nasabah hanya mencapai pulang pokok..

d) Pengkonversasian kredit jangka pendek menjadi kredit jangka panjang dengan syarat-syarat lebih ringan.

3. Restructuring

Adalah alternatif penyehatan kredit dengan cara menambah modal nasabah dengan pertimbangan nasabah memang membutuhkan tambahan dana dan usaha yang dibiayai memang masih layak. Tindakan ini dapat dilakukan dengan cara :

a. Tambahan kredit.

Apabila nasabah kekurangan modal kerja, maka perlu dipertimbangkan penanaman modal kerja, demikian juga dalam hal investasi, baik perluasan maupun tambahan investasi. 
b. Tambahan modal.

Apabila tambahan kredit memberatkan nasabah, sehubungan dengan pembayaran bunganya, maka perlu dipertimbangkan tambahan modal sendiri.

4. Kombinasi

Merupakan kombinasi dari ketiga jenis yang diatas. Seorang nasabah dapat saja diselamatkan dengan kombinasi antara Rescheduling misalnya jangka waktu diperpanjang modal ditambah.

5. Penyitaan jaminan.

Penyitaan jaminan merupakan jalan terakhir apabila nasabah benar-benar sudah tidak punya itikad baik ataupun sudah tidak mampu lagi untuk membayar semua hutang-hutangnya.

Dari uraian diatas disimpulkan bahwa faktor utama yang menjadi pertimbangan dalam upaya penyehatan kredit bermasalah adalah karakter, manajemen dan prospek usaha. Debitur bermasalah memungkinkan desehatkan apabila manajemennya terbuka dan memiliki rencana usaha yang jelas. Dalam pelaksanaan penyehatan kredit sering kali bank harus memberikan keringanan seperti suku bunga yang lebih rendah dari suku bunga komerial.

Pihak bank sering kurang menyetujui cara pemberian keringanan berupa penurunan suku bunga, namun bagaimanapun juga masih lebih baik penerimaan pendapatan bunga yang lebih kecil dari pada tidak sama sekali.

\section{Tata Cara Penyelesaian Kredit Bermasalah}

\section{A. Penagihan Kredit}

1. Kebijakan Umum

Penagihan kredit secara lansung oleh Bank merupakan upaya pertama yang dilakukan sebagai antisipasi atau tindakan prefentif atas gejala awal munculnya kredit bermasalah.

2. Langkah Pelaksanaan Penagihan

Dalam melakukan penagihan dapat dipedomani beberapa langkah berikut ini yang urutannya disesuaikan dengan peluang keberhasilannya, yaitu :

a. Investasi data tunggakan dan permasalahan yang menyebabkan kredit menjadi bermasalah.

b. Menetapkan prioritas penagihan, yaitu :

1) Kualitas kredit Dalam Perhatian Khusus.

2) Kualitas Kredit Kurang Lancar.

3) Kualitas kredit Diragukan.

4) Kualitas kredit Macet.

5) Kredit yang dicatat secara Ekstrakomtabel.

c. Melakukan pendekatan secara persuasif dengan Debitur, meliputi :

1) Menyurati dan memanggil debitur ke kantor.

2) Melakukan kunjungan secara rutin.

3) Membicarakan penyebab terjadinya kredit bermasalah.

4) Membicarakan langkah-langkah penyelamatan/penyelesaian kredit. 
5) Membuat action plan yang dituangkan dalam Daily client Visiting Report.

d. Menegosiasikan dengan debitur tentang langkah-langkah penyelesaian, seperti :

1) Penyelamatan kredit

2) Penyelesaian kredit

3) Pelunasan kredit

4) Angsuran dalam jangka waktu tertentu.

5) Angsuran dengan pemberian keringanan bunga dan denda kredit.

6) Penyelesaian melalui penjamin.

7) Menjual agaunan kredit

8) Dan lain lain

e. Membuat dan Menyampaikan Surat Teguran kepada Debitur :

1) Surat teguran kredit adalah pemberitahuan kepada debitur bahwa telah terjadi tunggakan pokok dan/atau bunga kreditb dengan suatu permintaan untuk segera menyelesaian tunggakan kewajiban tersebut. Surat tunggakan ditembuskan kepada Pemilik agunan dan penjamin kredit.

2) Surat teguran diberikan pada kesempatan pertama sejak penurunan kualitas kredit dari Lancar menjadi Dalam Perhatian Khusus.

3) Surat teguran dapat diberikan berulang-ulang selama kualitas kredit tergolong Dalam Perhatian Khusus.

4) Format Surat Teguran diatur dengan Surat Direksi Tersendiri.

f. Membuat dan Menyampaikan Surat Peringatan :

1) Surat peringatan adalah suatu permintaan/perintah dari bank kepada debitur intuk segera menyelesaikan kewajiban tunggakan pokok dan/atau bunga kredit yang telah jatuh tempo/tertunggak. Surat Peringatan ini disampaikan Bank kepada debitur apabila upaya pendekatan secara persuasif yang dilakukan terhadap debitur tidak membuahkan hasil yang diharapkan.

2) Pengaturan pemberian Surat Peringatan adalah sebagai berikut :

a) Surat Peringatan I (SP I) diberikan pada kesempatan pertama sejak penurunan kualitas kredit dari Dalam Perhatian Khusus menjadi Kurang Lancar,

b) Surat Peringatan II (SP II) ddiberikan pada kesempatan pertama sejak penurunan kualitas kredit dari Kurang Lancar menjadi Diragukan

c) Surat Peringatan III (SP III) diberikan pada kesempatan pertama sejak penurunan kualitas kredit dari Diragukan menjadi Macet.

3) Format Surat Peringatan diatur dengan Surat Direksi tersendiri.

4) Surat Peringatan ditembuskan kepada :

a) Pemilik agunan dan penjamin kredit.

b) Dan pihak yang dirasa perlu. 
g. Debitur menjual sendiri agunan kredit.

Debitur mencari sendiri pembeli agunan, dan dalam proses penjualannya harus mendapatkan persetujuan Bank.

h. Menjual berdasarkan Surat Kuasa dari Debitur dan atau Pemilik Agunan Debitur dan atau Pemilik agunan memberi Surat Kuasa kepada bank atau pihak lain untuk menjual agunan kredit guna penyelesaian tunggakan kredit di Bank. Format Surat Kuasa diatur dengan Surat Direksi tersebut.

i. Bank menjual agunan berdasarkan kesepakatan kedua belah pihak dengan tata cara sebagai berikut :

1) Adanya kesepakatan kedua belah pihak.

2) Harga jual sesuai

3) dengan harga yang berlaku umum.

j. Melakukan penagihan kepada penjamin kredit dengan tata cara sebagai berikut :

1) Memanggil penjamin kredit untuk datang ke Bank atau mengunjungi penjamin kredit.

2) Membicarakan langkah-langkah penyelesaian kredit yang dijaminnya.

3) Mempertemukan debitur dengan penjamin kredit.

k. Mengajukan klaim kepada Lembaga Penjamin Kredit yang ditutup dengan pertanggungan kredit.Tata cara dan prosedur penutupan pertanggungan dan pengajuan klaim serta pelaksanaan penyelesaian kredit mempedomani perjanjian kerja sama pertanggungan kredit antara Bank dengan Lembaga Penjamin dimaksud.

1. Menyerahkan penyelesaian kredit bermasalah kepada Pihak Ketiga yang Berwenang.

\section{B. Restrukturisasi Kredit}

1. Umum

a. Restrukturisasi Kredit adalah upaya perbaikan yang dilakukan Bank dalam kegiatan perkreditan terhadap debitur yang mengalami kesulitan untuk memenuhinkewajibannya kepada Bank, yang dilakukan antara lain :

1) Penurunan suku bunga kredit.

2) Perpanjangan jangka waktu.

3) Pengurangan tunggakan bunga kredit.

4) Pengurangan tunggakan pokok kredit.

5) Penambahan fasilitas kredit.

6) Konversi Kredit menjadi Penyertaan Modal Sementara.

b. Bank hanya dapat melakukan Restrukturisasi Kredit terhadap debitur yang memenuhi kriteria sebagai berikut :

1) Debitur menghalami kesulitan pembayaran pokok dan/atau bunga kredit,

2) Debitur memiliki prospek usaha yang baik dan mampu memenuhi kewajiban setelah Kreit direstrukturisasi. 
c. Bank dapat melakukan Restrukturisasi Kredit dalam bentuk Penyertaan Modal Sementara dengan ketentuan sebagai berikut ;

1) Penyertaan Modal Sementara hanya dapat dilakukan untuk kredit yang memiliki kualitas Kurang Lancar, Diragukan atau Macet.

2) Penyertaan Modal Sementara wajib ditarik kembali apabila telah melampaui jangka waktu paling lama 5 (lima) tahun atau perusahaan debitur tempat penyertaan telah memperoleh laba kumulatif.

3) Penyertaan Modal Sementara wajib dihapusbukukan dari neraca Bank apabila telah melampaui jangka waktu 5 (lima) tahun.

Restrukturisasi dengan cara penyertaan modal mempedomani ketentuan Bank Indonesia yang berlaku.

d. Bank dilarang melakukan Restrukturisasi kredit dengan tujuan hanya untuk menghindari :

1) Penurunan penggolongan kualitas kredit,

2) Peningkatan pembentukan Penyisihan Penghapusan Aktiva (PPA) untuk kredit.

3) Penghentian pengakuan pendapatan bunga secara akrual.

2. Penetapan Kualitas Kredit

Dalam rangka pelaksanaan Restrukturisasi Kredit, Bank wajib menetapkan kualitas kredit terhadap yang telah direstyrukturisasi dengan penetapan kualitas kredit sebagai berikut :

a. Kualitas kredit setelah dilakukan restrukturisasi ditetapkan sebagai berikjut :

1) Setinggi-tingginya Kurang Lancar untuk kredit yang sebelum dilakukan restrukturisasi tergolong Diragukan atau Macet,

2) Kualitas tidak berubah untuk Kredit yang sebelum dilakukan restrukturisasi tergolong Lancar, Dalam Perhatian Khusus atau Kurang Lancar.

b. Kualitas kredit setelah dilakukan restrukturisasi ditetapkan sebagai berikut :

1) Kualitas kredit sebagai mana dimaksud pada huruf a diatas dapat :

a) Menjadi Lancar, apabila tidak terdapat tunggakan selama 3 (tiga) kali periode pembayaran angsuran pokok dan agtau bunga kredit secara berturut-turut sesuai dengan perjanjian Restrukturisasi Kredit, atau

b) Kembali sesuai dengan kualitas kredit sebelum dilakukan Restrukturisasi kredit atau kualitas yang sebenarnya apabila lebih buruk sesuai dengan kriteria sebagaimana yang diatur dalam ketentuan penetapan kualitas kredit dan atau syarat-syarat dalam perjanjian Restrukturisasi kredit 
dan atau pelaksanaan Restrukturisasi kredit tidak didukung dengan analisis dan dokumentasi yang memadai.

2) Dalam hal periode pembayaran angsuran pokok dan//atau bunga kredit kurang dari 1 (satu) bulan, peningkatan kualitas menjadi Lancar sebagaimana dimaksud pada angka 1) huruf a) dapat dilakukan secepat-cepatnya dalam waktu 3 (tiga) bulan sejak dilakukan Restrukturisasi kredit.

3) Ketentuan sebagaimana dimaksud pada huruf a) sampai dengan angka 2) berlaku juga untuk restrukturisasi ulang terhadap kredit.

4) Tambahan Kredit sebagai bagian dari paket Restrukturisasi kredit ditetapkan memiliki kualitas Lancar apabila diberikan sesuai dengan prosedur yang ketat dan memiliki agunan yang cukup.

5) Kredit yang direstrukturisasi dengan pemberian tenggang waktu pembayaran (grace period) untuk pembayaran pokok dan bunga kredit ditetapkan memiliki kualitas sebagai berikut :

a) Selama grace period, kualitas mengikuti kualitas kredit sebelum dilakukan restrukturisasi.

b) Setelah grace period berakhir, kualitas kredit mengikuti penetapan kualitas sebagaimana dimaksud angka 1) sampai dengan angka 5) diatas.

6) Penilaian kualitas kredit yang telah direstrukturisasi dan kualitas tambahan kredit sebagai bagian dari paket Restrukturisasi kredit wajib dilakukan sesuai dengan peraturan Bank Indonesia yang berlaku.

7) Penilaian kualitas kredit tidak memenuhi kriteria dan atau syarat-syarat dalam perjanjian Restrukturisasi kredit sebagaimana dimaksud diatas, weajib dilakukan sesuai dengan Peraturan Bank Indonesia yang berlaku.

8) Penetapan kualitas kredit yang sama berlaku pula terhadap kredit yang direstrukturisasi sabagai berikut :

a) Bank wajib menetapkan kualitas yang sama terhadap kredit yang digunakan untuk membayar 1 (satu) debitur.

b) Penetapan kualitas yang sama terhadap kredit sebagaimana dimaksud pada butir a) berlaku pula terhadap kredit yang digunakan untuk membiayai proyek yang sama.

c) Dalam hal terdapat penetapan kualitas terhadap kredit sebagaimana dimaksud pada butir a) dan b), kualitas masingmasing kredit mengikuti kualitas kredit yang paling rendah.

d) Ketentuan sebagaimana dimaksud pada butir c) dapat dikecualikan dalam hal kredit ditetapkan berdasarkan faktor penilaian yang berbeda. 
e) Penetapan kualitas yang sama terhadap kredit sebagaimana dimaksud dalam butir a) dan b) berlaku pula terhadap kredit yang diberikan oleh lebih dari 1 (satu) Bank yang digunakan untuk membiayai 1 (satu) proyek yang sama.

f) Ketentuan sebagaimana dimaksud pada butir e) berlaku untuk:

(1) Kredit yang diberikan oleh setiap Bank dengan jumlah lebih dari Rp 10.000.000.000,- (sepuluh milyar rupiah) kepada 1) (satu) debitur atau 1 (satu) proyek yang sama,

(2) Kredit yang diberikan oleh setiap Bank dengan jumlah lebih dari Rp 500.000.000,- (lima ratus juta rupiah) sampai dengan Rp 10.000.000.000,- (sepuluh milyar rupiah) kepada 1 (satu) debitur, yang merupakan 50 (lima puluh) debitur terbesar bank, dan atau

(3) Kredit yang diberikan berdasarkan perjanjian pembiayaan bersama kepada 1 (satu) debitur atau 1 (satu) proyek yang sama.

g) Dalam hal terdapat perbedaan penetapan kualitas terhadap kredit sebagaimana dimaksud pada butir e) dan f), kualitas yang ditetapkan terhadap kredit tersebut mengikuti kualitas kredit yang paling rendah.

h) Tidak termasuk dalam pengertian kualitas kredit yang paling rendah sebagaimana dimaksud pada butir g) adalah :

(1) Kualitas kredit yang ditetapkan dengan menggunakan factor penilaian tambahan berupa resiko Negara (Country risk) Republik Indonesia, dan atau

(2) Kualitas kredit yang telah dihapus tagih.

i) Ketentuan bagaimana dimaksud pada butir g) dapat dikecualikan dalam hal kredit ditetapkan berdasarkan factor penilaian yang ber beda.

9) Bank dapat tidak menetapkan kualitas yang sama untuk kredit yang diberikan kepada 1 (satu) debitur yang sama sebagaimana dimaksud dalam point 8 butir a), e), f) dan g) sepanjang debitur memenuhi persyaratan paling kurang sebagai berikut :

a) Debitur memiliki beberapa proyek yang berbeda, dan

b) Terdapat pemisahan yang tegas antara arus kas ( cash flow ) dari masing-masing proyek.

c) Bank yang tidak menetapkan kualitas yang sama untuk kredit yang diberikan kepada 1 (satu) debitur sebagaimana dimaksud pada butir 9 wajib :

a) Menginformasikan kepada Bank Indonesia daftar yang memuat nama debitur beserta rincian masing-masing debitur yang meliputi proyek yang dibiayai, plafond 
dan baki debet kredit, kualitas yang ditetapkan oleh Bank lain, dan alasan penetapan kualitas yang berbeda, dan

b) Mendokumentasikan hal-hal yang terkait dengan penetapan kualitas sebagaimana dimaksud pada point 9.

3. Penyisihan Penghapusan dan Pengakuan Pendapatan

Dalam rangka pelaksanaan Restrukturisasi Kredit, Bnak membentuk Penyisihan Penghapusan Aktiva (PPA) untuk kredit yang direstrukturisasi dan melakukan akuntansi terhadap pengakuan pendapatan dari kredit yang direstrukturisasi dengan ketentuan sebagai berikut :

a. Penyisihan Penghapusan Aktiva (PPA) terhadap kredityang telah direstrukturisasi.

1) Bank wajib membentuk PPA terhadap kredit yang telah direstrukturisasi sesuai dengan Peraturan Bank Indonesia yang berlaku.

2) Bank wajib membebankan kerugian yang timbul dari Restrukturisasi Kredit, setelah diperhitungkan dengan kelebihan PPA karena perbaikan kualitas kredit setelah dilakukan Restrukturisasi Kredit.

3) Kelebihan PPA karena perbaikan kualitas kredit yang direstrukturisasi sebagaimana dimaksud pada angka 2) diatas, setelah diperhitungkan dengan kerugian yang timbul dari Restrukturisasi kredit dimaksud, hanya dapat diakui sebagai Pendapatan apabila telah terdapat penerimaan angsuran pokok atas kredit yang direstrukturisasi.

4) Pengakuan Pendapatan sebagaimana dimaksud angka 3) diatas dilakukan secara profesional dengan angsuran pokok dari kredit yang direstrukturisasi.

b. Pengakuan Pendapat dari Kredit yang Direstrukturisasi.

Pendapatan bunga dan penerimaan lain dari Kredit yang direstrukturisasi hanya dapat diakui apabila telah diterima secara tunai sebelum kualitas Kredit menjadi Lancar.

\section{KESIMPULAN}

Berdasarkan uraian diatas yang telah dikemukakan, maka dapat ditarik kesimpulan sebagai berikut :

1. PT. Bank Perkreditan Rakyat (BPR) Mitra Danagung merupakan bank yang bergerak dibidang memberikan pinjaman dalam bentuk kredit yang tujuannya adalah untuk membantu masyarakat yang kekurangan dana yang berada disekitar kota padang.

2. Dalam pelaksanaan pengawasan kredit PT BPR Mitra Danagung didasarkan penelitian ketempat lokasi usaha debitur serta atas laporan-laporan yang diberikan oleh nasabah. 
3. Untuk keamanan dari kredit yang diberikan kepada nasabah, maka PT BPR Mitra Danagung meminta adanya jaminan kredit kepada calon nasabah.

4. Penyehatan kredit bermasalah yang dilakukan oleh PT BPR Mitra Danagung dapat dilakukan dengan cara kombinasi yaitu dengan cara memberi surat tunggakan dan surat peringatan kepada debitur, memberikan keringanan pembayaran bunga dan tunggakan pokok, serta mendesak debitur untuk menjual agunan.

5. Penyebab utama dari kredit bermasalah bisa saja karena kesalahan dari pihak bank yang kurang tajam dalam menganalisis latar belakang calon nasabah, sehingga maksud dan tujuan serta sumber pembayaran kembali kredit yang diberikan tidak dapat diketahui secara jelas. Rendah nya tingkat pendidikan nasabah yang menerima kredit, serta kurang adanya komunikasi yang terbuka antara nasabah dengan bank juga dapat menyebabkan terjadinya kredit bermasalah.

\section{DAFTAR PUSTAKA}

Afriyeni, A. (2019). Mekanisme Transaksi Dan Sistem Perhitungan Bunga Kredit Usaha Mikro Kecil Dan Menengah (UMKM) Pada PT. Pegadaian (Persero) Cabang Ulak Karang. https://doi.org/10.17605/OSF.IO/WB2E6

Alanshari, F., \& Marlius, D. (2018). Prosedur Pemberian Kredit KPR Pada PT. Bank Tabungan Negara (Persero) TBK Cabang Pembantu Bukittinggi. https://doi.org/10.31227/osf.io/rsfhc

Amelia, L., \& Marlius, D. (2018). Pengendalian Kredit Dalam Upaya Menciptakan Bank Yang Sehat Pada PT. Bank Pembangunan Daerah Sumatera Barat Cabang Utama Padang. https://doi.org/10.31227/osf.io/kpc64

Andriani, B., \& Susanto, R. (2019). Pengawasan Kredit PT. Bank Perkreditan Rakyat (BPR) Ophir Pasaman Barat. https://doi.org/10.31219/osf.io/aunvc

Baiya, \& Fernos, J. (2019). Analisis Faktor-Faktor Penyebab Kredit Macet Pada Bank Nagari Cabang Siteba. https://doi.org/10.31227/osf.io/4xuks

Darmawanto, \& Fernos, J. (2019). Prosedur Pemberian Kredit Pada Bank Nagari Cabang Sijunjung. https://doi.org/10.31227/osf.io/psqfy

Febriansyah, I., \& Afriyeni, A. (2019). Penyelesaian Kredit Bermasalah PT. Bank Pembangunan Daerah (BPD) Sumbar Cabang Alahan Panjang Kabupaten Solok. https://doi.org/10.31219/osf.io/vutmj 
Firmansyah, A., \& Fernos, J. (2019). Analisis Kredit Bermasalah Dilihat Dari Standar Non Performing Loan (NPL) Pada PT. Bank Perkreditan Rakyat (BPR) Prima Mulia Anugrah Cabang Padang. https://doi.org/10.31227/osf.io/gcj94

Ikbal, M., \& Marlius, D. (2017). Pengaruh Jumlah Taksiran Dan Uang Pinjaman Terhadap Laba Bersih Pada PT. Pegadaian (UPC) Gurun Laweh. https://doi.org/10.31227/osf.io/uch4a

Kasmir, Bank dan Lembaga Keuangan Lainnya, PT Raja Grafindo Persada, jakarta, 2011

Kasmir, Dasar-Dasar Perbankan, PT Grafindo Persada, Jakarta, 2003

Rivai Veithzal \& Anria Permata Veithzal, Credit Management Handbook, PT Raja Grafindo Persada, 2006

Sutojo, Siswanto, Menangani Kredit Bermasalah, PT Damar Mulia Pustaka, Jakarta, 2008

Suyatno, Thomas, Dasar-Dasar Perhreditan, PT Gramnedia Pustaka Utama, Jakarta, 2003

Undang-Undang RI No, 10 tahun 1998 Tentang Perbankan, Citra Umbara, Bandung, 2002

Undang-undang No.10 tahun 1998 tentang perubahan atas undang-undang No.7 tahun 1992 tentang perbankan. Citra Umbara: Bandung.

Widayati, R. (2019). Penyelesaian Kredit Bermasalah Pada PT. Bank Perkreditan Rakyat (BPR) Nagari Kasang. https://doi.org/10.17605/OSF.IO/D4MF3

Widayati, R. (2019). Pelaksanaan Prinsip Kehati-Hatian Dalam Pemberian Kredit Konsumtif Pada Bank Nagari Cabang Siteba. https://doi.org/10.17605/OSF.IO/FZVXR

Widayati, R. (2019). Aktivitas Pemberian Kredit Komersil Pada Bank Nagari Cabang Sijunjung. https://doi.org/10.17605/OSF.IO/QTVZ9

Widayati, R. (2019). Pelaksanaan Kredit Pada Bank Perkreditan Rakyat LPN Pasar Baru Durian Sawahlunto. https://doi.org/10.17605/OSF.IO/5HPAB

Widayati, R. (2019). Upaya Penanganan Kredit Bermasalah Pada Bank Nagari Cabang Utama Padang. https://doi.org/10.17605/OSF.IO/YJ3KN 
Widayati, R. (2019). Aktivitas Pemberian Kredit Usaha Pada PT. Bank Perkreditan Rakyat Batang Kapas. https://doi.org/10.17605/OSF.IO/EDPN4

Yasman, R., \& Afriyeni, A. (2019). Prosedur Pemberian Kredit Pada PT. Bank Pekreditan Rakyat (BPR) Jorong Kampung Tangah (JKT) Pariaman Cabang Padang. https://doi.org/10.31219/osf.io/c5ufr 